\title{
4143 歳児有限要素人体モデルの生体忠実性向上
}

\author{
Biofidelity Advancement of 3-Year-Old Child FE Human Model
}

正 小泉孝之 (同志社大) 正 辻内伸好 (同志社大)

○学 瀧 宣博 (同志社大院)

Takayuki KOIZUMI, Nobutaka TSUJUUCHI, Doshisha University, Kyotanabe-City, Kyoto Nobuhiro TAKI, Doshisha University Graduate School, Kyotanabe-City, Kyoto

Key Words: Finite Element Method, HUMOS-2, Impact Response Test, Scaling, Child

\section{1. 緒言}

近年, コンピューター技術の発達に伴い，人体のモデル 化に関する研究が盛んに行われている，その結果，自動車 衝突時における人体の詳細な傷害評価が可能となってきて いる。しかし，これらのモデルの多くは成人を対象とした モデルであり，幼児を対象としたモデルはほとんど存在し ない. そこで，これまでの研究により，3 歳児有限要素人 体モデルが開発された ${ }^{1)}$ 。このモデルは, MADYMO 内に 存在する成人有限要素人体モデル(HUMOS モデル)をスケ ールダウンすることにより開発された。しかし，開発され たモデルは多くの改善を必要とする，その一つとして，生 体忠実性の向上が挙げられる。

そこで本研究では，3 歳児有限要素人体モデルの生体忠 実性の向上を目的とし，新たに HUMOS-2 モデルを用いて 3 歳児有限要素人体モデルの再構築を行った。また，再構 築したモデルの生態忠実性を評価するため，衝撃応答試験 を行った.

\section{HUMOU-2 モデル概要}

HUMOS(HUman MOdeling for Safety)モデルは，ヨーロッ パの人体モデル化プロジェクトで開発された人体モデルで ある. モデルは, 皮膚, 骨格, 臓器等から再現されており, PMHS やボランティアによる実験との比較によって，モデ ルの妥当性が検証されている. HUMOS-2 モデルはこの HUMOS モデルの生体忠実性，ロバスト性を向上させるこ とを目的に開発され，メッシュクォリティや材料特性等が 改善されている2). Fig. 1 に HUMOS-2 モデルを示す.

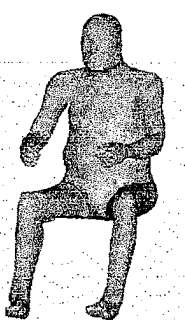

(a) Soft Tissue

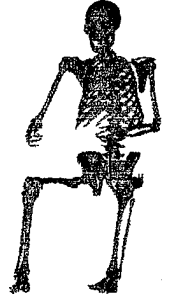

(b) Skeletons

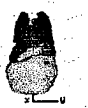

(c) Organs
Fig.1 50\%ile Adult FE Human Model (HUMOS-2 model) 本研究では，この HUMOS-2 モデルを用いて 3 歳児有限 要素人体モデルを再構築した．また，以下の文中にある 3 歳児有限要素人体モデルは HUMOS-2 から再構築した 3 歳 児有限要素人体モデルを指す。

\section{3 瓷児有限要素人体モデルの作成}

成人有限要素人体モデルから 3 歳児有限要素人体モデル にスケーリングする際のスケーリング項目は，人体形状， 関節特性，材料特性の 3 点である.ここでは人体形状のス ケーリングについて述べる.

本研究では 3 歳児の人体測定值として, CANDAT データ ベースを参考にし, 欧米の平均的な 3 歳児の体型を目標と したまま，メッシュスケーリング及び関節位置のスケー リングには, 成人と 3 歳児の形状の違いを精度·効率良く再 現するために，地球統計学で広く用いられている通常型 Kriging 法を用いた. スケーリング方法として, まず成人有 限要素人体モデルより，CANDAT データベースに対応する 節点を抽出する，この時の成人モデルにおける各節点座標 を $\mathbf{X}_{\alpha}$, スケーリング係数を $\lambda\left(\mathbf{X}_{\alpha}\right)$ とし, 重み係数 $\omega_{\alpha}$ を用 いると，任意の位置 $\mathbf{X}$ におけるスケーリング倸数 $\lambda^{*}(\mathbf{X})$ は 次式で表される. 


$$
\lambda^{*}(\mathbf{X})=\sum_{\alpha=1}^{n} \omega_{\alpha} \lambda\left(\mathbf{X}_{\alpha}\right)
$$

既知のスケーリング保数は一定值をとるので，重み係数 の総和は 1 をとなる. この時, 推定分散 $\sigma_{E}{ }^{2}$ は,

$$
\sigma_{E}^{2}=E\left[\left(\lambda^{*}(\mathbf{X})-\lambda(\mathbf{X})\right)^{2}\right]
$$

と表される.この推定分散を最小化すると，次式の通常型 Kriging システムが得られる.

$$
\begin{gathered}
\sum_{\beta=1}^{n} \omega_{\beta} \gamma\left(\mathbf{X}_{\alpha}-\mathbf{X}_{\beta}\right)+\mu=\gamma\left(\mathbf{X}_{\alpha}-\mathbf{X}\right) \\
(\alpha=1,2, \cdots n) \\
\sum_{\beta=1}^{n} \omega_{\beta}=1
\end{gathered}
$$

ここで, $\mu$ をラグランジュ乗数， $\mu$ を理論バリオグラムと する.この Kriging 推定システムを用いることにより，ス ケーリング係数が既知である座標から，未知の座標におけ るスケーリング係数が算出可能となる. Fig.2 に頭䡈部にお けるZ 軸方向のスケーリング係数の分布図を示す.

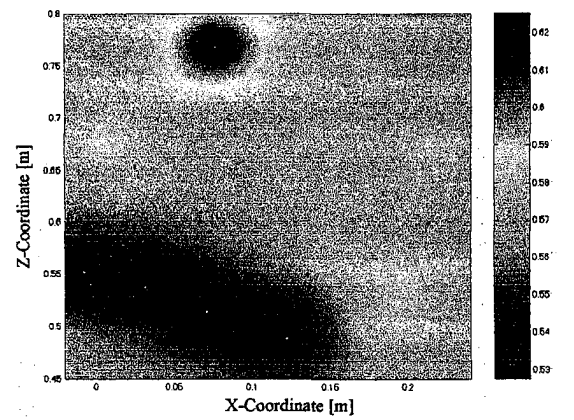

Fig.2 Z-Coordinate Scaling Factor Map for Head-Neck Part このような分布図を人体各部位, 各軸方向に対して作成す ることによって，メッシュスケーリング及び関節位置のス ケーリングを行った.

\section{4. 衝撃応答試験}

再構築した 3 歳児有限要素人体モデルの生体忠実性を評 価するために，衝撃応答試験を行った，試験要件として， 本研究ではこれまでと同様に, Q3 ダミーの性能要件 ${ }^{3)}$ を用 いた．また，衝撃応答試験の一例として，ここでは前面胸 部衝擊試験について述べる.

シミュレーション条件として，人体モデルを剛体面に着 座させ，インパクターを胸骨中心に衝突するように配置し た. インパクターの直径は $82[\mathrm{~mm}]$, 質量は $3.8[\mathrm{~kg}]$ となる ようにモデル化を行った．そして，初速度 $4.3[\mathrm{~m} / \mathrm{s}]$ および $6.7[\mathrm{~m} / \mathrm{s}]$ で衝突させた. Fig.3 に前面胸部衝撃試験の概観を 示す.

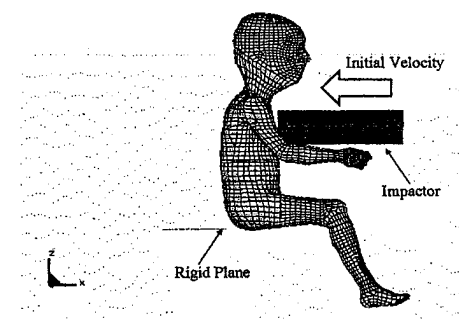

Fig.3 Setup of Frontal Thoracic Impact Test

\section{5. 結言}

本研究では, 3 歳児有限要素人体モデルの生体忠実性の 向上を目的とし，HUMOS-2 モデルを用いて 3 歳児有限要 素人体モデルの再構筑を行った，その結果，以下の結論が 得られた。

(1) HUMOS-2 モデルを用いて，3 歳児有限要素人体モデル を再構築した.

(2) Kriging 法を用いることにより，成人と 3 歳児の人体形 状の違いを考慮した 3 歳児の人体形状を再現した.

(3) 構築したモデルの生体忠実性を評価するため, 前面胸 部衝撃試験を行った.

今後, 再構筑した 3 歳児有限要素人体モデルを用いて， 前面胸部衝撃試験以外の衝撃応答試験を行っていく予定で ある。

\section{謝辞}

なお本研究は, 文部科学省からの補助を受けた同志社大 学の学術フロンティア研究プロジェクト「知能情報科学と その応用」に扔ける研究の一環として行った。

\section{参考文献}

1）内田泰裕 他, 3 歳児有限要素人体モデルを用いた衝突傷 害予測, 2004 自動車技術会秋季学術講演会論文, 2004

2) TNO Automotive, MADYMO Human Models Manuals 6.3, pp.55-76, 2005

3) M.R.van Ratingen, et al., Based Design and Performance Targets for a 3-Year Old Child Crash Dummy for Frontal and Side Impact, SAE Technical Paper Series, 973316, 1997 